\title{
Messenger RNA expression of TS and ERCC1 in colorectal cancer and matched liver metastasis
}

\author{
HIROTOSHI KOBAYASHI ${ }^{1,2}$, KENICHI SUGIHARA ${ }^{1}$, HIROYUKI UETAKE ${ }^{1}$, \\ TETSURO HIGUCHI $^{1}$, MASAMICHI YASUNO ${ }^{1}$, MASAYUKI ENOMOTO ${ }^{1}$, \\ SATORU IIDA ${ }^{1}$, MIZUTOMO AZUMA ${ }^{2}$, RYUTARO MORI ${ }^{2}$, AKIKO OMORI ${ }^{2}$, \\ HEINZ-JOSEF LENZ ${ }^{3}$, KATHLEEN D. DANENBERG ${ }^{4}$ and PETER V. DANENBERG ${ }^{2}$ \\ ${ }^{1}$ Department of Surgical Oncology, Graduate School, Tokyo Medical and Dental University, Tokyo, Japan; \\ ${ }^{2}$ Departments of Biochemistry and Molecular Biology, ${ }^{3}$ Medical Oncology, University of Southern California, \\ Norris Comprehensive Cancer Center, Los Angeles, CA; ${ }^{4}$ Response Genetics, Inc., Los Angeles, CA, USA
}

Received June 4, 2008; Accepted August 28, 2008

\section{DOI: 10.3892/ijo_00000116}

\begin{abstract}
FU) and oxaliplatin play important roles in chemotherapy for patients with colorectal cancer. The expression levels of thymidylate synthase (TS) and excision repair cross-complementing factor 1 (ERCC1) have been reported to be prognostic markers for patients with 5-FU/oxaliplatin chemotherapy. The aim of this study was to clarify the association between messenger RNA (mRNA) levels of TS and ERCC1 in primary colorectal cancer and those in corresponding liver metastasis. Formalin-fixed paraffinembedded tumor specimens of 31 patients with resection for both colorectal cancer and liver metastasis were dissected by laser capture microdissection. After RNA extraction, TS and ERCC1 mRNA levels in both primary tumor and corresponding liver metastasis were measured by real-time reverse transcription-polymerase chain reaction. Both TS and ERCC1 mRNA levels in primary tumors were significantly associated with those in synchronous liver metastases (TS, rs $=0.875$, $\mathrm{p}=0.0024 ; E R C C 1, \mathrm{rs}=0.835, \mathrm{p}=0.0038$ ). TS mRNA levels in primary tumors were also associated with those in metachronous liver metastases ( $\mathrm{rs}=0.659, \mathrm{p}=0.0065$ ), but not in ERCC1 ( $\mathrm{rs}=0.319, \mathrm{p}=0.19$ ). In both genes, mRNA levels in metachronous liver metastases were higher than those in primary tumors $(T S, \mathrm{p}=0.0084 ; E R C C 1, \mathrm{p}=0.037)$. However, there was no difference in the TS and ERCC1 mRNA levels between primary tumors and synchronous liver metastasis. The measurement of TS and ERCC1 mRNA levels in
\end{abstract}

Correspondence to: Dr Hirotoshi Kobayashi, Department of Surgical Oncology, Tokyo Medical and Dental University, 1-5-45 Yushima, Bunkyo-ku, Tokyo, Japan

E-mail: h-kobayashi.srg2@tmd.ac.jp

Key words: colorectal cancer, liver metastasis, thymidylate synthase, excision repair cross-complementing factor 1 , reverse transcriptionpolymerase chain reaction primary colorectal cancer can predict those in synchronous liver metastases, but not in metachronous ones.

\section{Introduction}

Malignant neoplasm is a leading cause of death in Japan. Colorectal cancer is the second leading cause of cancer deaths in the United States and the third in Japan (1). Colorectal cancer is still increasing in Japan (2) and it is considered as a result of westernized dietary habit. Metastasis is the main reason why colorectal cancer is fatal. The most frequent metastatic site from colorectal cancer is the liver (3). Therefore, it is of great importance to improve the treatment results for liver metastasis. The best way to cure liver metastasis from colorectal cancer is to resect the lesions completely. However, some patients are not eligible for surgical resection. In these cases, chemotherapy plays an important role for their treatments.

Chemotherapy for colorectal cancer has made great progress, since Moertel et al reported that adjuvant treatment with fluorouracil (5-FU) and levamisole reduced mortality rate by $33 \%$ in patients with Dukes' C colon cancer. Several studies have established as the standard chemotherapy with 5-FU and leucovorin (LV) for colorectal cancer (4-6).

Oxaliplatin, a new cytotoxic agent from the diaminocyclohexane platinum family, forms cross-linking adducts and interferes with DNA replication and transcription (7). Several clinical trials have clarified the efficacy of FOLFOX, a combined chemotherapy with oxaliplatin, 5-FU, and LV, for metastatic colorectal cancer (8-10). FOLFOX improved the median survival in patients with metastatic colorectal cancer up to 20 months. It was 4 to 5 months for patients who did not receive chemotherapy. At the present time, FOLFOX plays a vital role in chemotherapy for metastatic colorectal cancer. Although these cytotoxic combined therapies have a beneficial effect on the treatment for such patients, there is a possibility of severe adverse effects. In some cases, these adverse effects can be fatal. Therefore, it would be useful to predict the efficacy of FOLFOX before treatment. The 
prediction of efficacy for such treatments would also avoid useless treatments.

Thymidylate synthase (TS) is the target enzyme of the antimetabolite 5-FU. Several studies reported that the gene expression level of intratumoral TS is a predictor of 5-FUbased chemotherapy $(11,12)$.

The excision repair cross-complementing factor 1 (ERCC1) is an excision nuclease within the nucleotide excision repair pathway (13-15). It is well known that ERCC1 has an effect on repair of platinum-DNA damage. Human ovarian cancer cells that express ERCC1 mRNA to higher levels showed higher resistance to platinum drug exposures (16). Shirota et al reported that ERCC1 and TS mRNA levels predicted survival for colorectal cancer patients receiving chemotherapy with oxaliplatin and 5-FU (17).

FOLFOX is used for patients with advanced colorectal cancer, such as those with hematogenous metastasis. However, the association between mRNA levels of TS and ERCC1 in primary colorectal cancer and those in liver metastasis is still unclear. In this study, we evaluated the mRNA levels of TS and ERCC1 in both primary colorectal cancer and corresponding liver metastasis.

\section{Materials and methods}

Patients. Thirty-one patients, who underwent surgical resections for both primary colorectal cancer and liver metastasis between April 1997 and June 2005 at Tokyo Medical and Dental University Hospital, were enrolled in this study. The patient characteristics were: the male:female ratio was 18:13; median age was 62 years. The median postoperative follow-up period was 49 months. Of 31 patients, 18 had a metachronous liver metastasis and 13 had a synchronous metastasis. Median time from primary resection to hepatectomy was 20 months in patients with metachronous liver metastasis. Patients with ulcerative colitis, Crohn's disease, or familial adenomatous polyposis were excluded in this study. This study was approved by the Institutional Review Board of Tokyo Medical and Dental University and all patients gave written consent. Stage III patients with metachronous liver metastasis had 5-FU-based adjuvant chemotherapy before hepatectomy. Other clinicopathological characteristics are summarized in Table I.

Laser capture microdissection. Formalin-fixed paraffinembedded tissue blocks were cut into $10-\mu \mathrm{m}$ thickness. Slides of $10 \mu \mathrm{m}$ thickness were stained with nuclear fast red (American MasterTech Scientific, Lodi, CA). After this staining, laser capture microdissection (P.A.L.M. Microlaser Technologies AG, Munich, Germany) was performed to punch out only tumor tissue.

RNA isolation and cDNA synthesis. After laser capture microdissection, RNA isolation was done according to a proprietary procedure of Response Genetics, Inc (US patent number $6,248,535)$. After RNA isolation, cDNA was prepared from each sample, as previously described (18).

Quantitative reverse transcription-polymerase chain reaction (QRT-PCR). Quantification of TS, ERCC1 and an internal
Table I. Clinicopathological characteristics in 31 patients.

\begin{tabular}{lr}
\hline Primary site & \\
Cecum & 1 \\
Ascending & 3 \\
Transverse & 3 \\
Descending & 2 \\
Sigmoid & 9 \\
Rectosigmoid & 9 \\
Rectum & 4 \\
Pathology of primary cancer & \\
Well differentiated & 13 \\
Moderately differentiated & 16 \\
Poorly differentiated & 1 \\
Mucinous & 1 \\
Depth of primary tumor & \\
T1 & 0 \\
T2 & 21 \\
T3 & 8 \\
T4 & 13 \\
Lymph node metastasis in primary tumor & 9 \\
N0 & 13 \\
N1 & \\
N2 & \\
Stage I & 1 \\
Stage II & \\
Stage III & \\
Stage IV & \\
\hline & \\
\hline
\end{tabular}

reference gene ( $($-actin) was performed using a fluorescencebased real-time detection method [ABI PRISM 7900 Sequence Detection System (Taqman); Applied Biosystems, Foster City, CA], as previously described (19). The primers and probe sequences in this study are shown in Table II. The PCR mixture consisted of $1,200 \mathrm{nmol} / 1$ of each primer, $200 \mathrm{nmol} / 1$ probe, 0.4 units of AmpliTaq Gold Polymerase, $200 \mathrm{nmol} / \mathrm{l}$ each of dATP, dCTP, dGTP, dTTP, $3.5 \mathrm{mmol} / 1 \mathrm{MgCl}_{2}$ and $1 \mathrm{X}$ Taq Man buffer A containing a reference dye, to a final volume of $20 \mu 1$ (all reagents were supplied by Perkin-Elmer Applied Biosystems). Cycling conditions were $50^{\circ} \mathrm{C}$ for $2 \mathrm{~min}, 95^{\circ} \mathrm{C}$ for $10 \mathrm{~min}$, followed by 46 cycles at $95^{\circ} \mathrm{C}$ for $15 \mathrm{sec}$ and $60^{\circ} \mathrm{C}$ for $1 \mathrm{~min}$. All the expression values (relative mRNA levels) are expressed as ratios between the genes of interest and an internal reference gene (B-actin).

Statistical analysis. All data are expressed as mean \pm standard deviation. To compare the mRNA levels of the genes of interest between primary colorectal cancer and corresponding liver metastasis, Wilcoxon signed-rank test was used. Spearman's rank correlation analysis determined the correlation of mRNA levels of the genes of interest between primary tumor and liver metastasis. Statistical significance was established at $\mathrm{P}<0.05$ for all results. 
Table II. Primer and probe sequences of the analyzed genes.

Primer and probe sequences

TS

Forward primer

Reverse primer

Probe

\section{ERCC1}

Forward primer

Reverse primer

Probe

ß-actin

Forward primer

Reverse primer

Probe

\author{
5'-GCCTCGGTGTGCCTTTCA-3' \\ 5'-CCCGTGATGTGCGCAAT-3' \\ 5'-(FAM)TCGCCAGCTACGCCCTGCTCA(TAMRA)-3'
}

\author{
5'-GGGAATTTGGCGACGTAATTC-3' \\ 5'-GCGGAGGCTGAGGAACGA-3' \\ 5'-(FAM)CACAGGTGCTCTGGCCCAGCACATA(TAMRA)-3'
}

\author{
5'-TGAGCGCGGCTACAGCTT-3' \\ 5'-TCCTTAATGTCACGGACGATTT-3' \\ 5'-(FAM)ACCACCACGGCCGAGCGG(TAMRA)-3'
}

$\mathbf{A}$

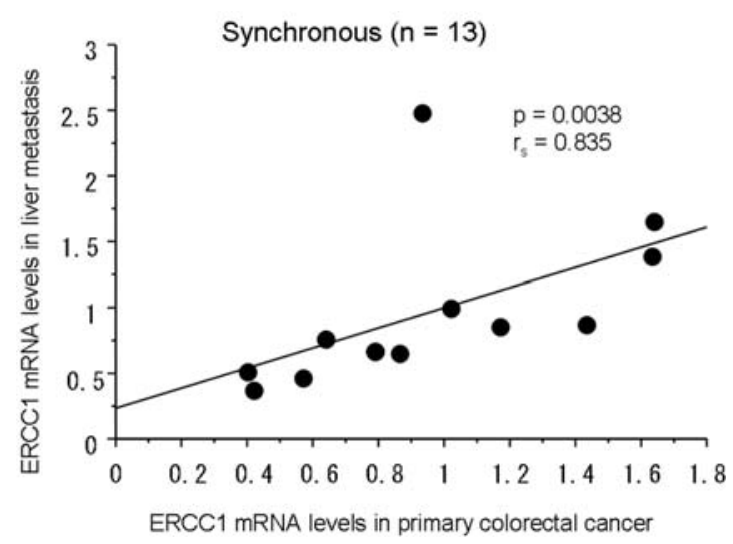

B

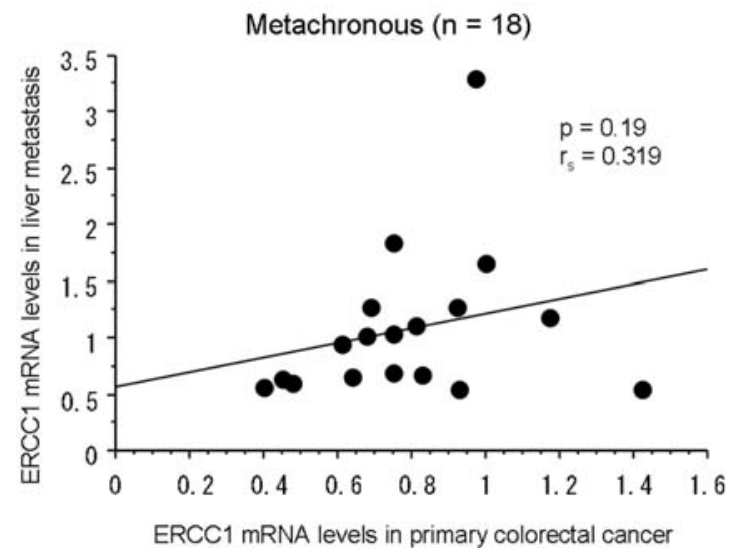

Figure 1. The correlation between ERCC1 mRNA levels in primary colorectal cancer and those in liver metastasis. (A) There was a significant positive correlation in case of synchronous liver metastasis. (B) ERCC1 mRNA levels in primary tumor were not significantly associated with those in metachronous liver metastasis.

\section{Results}

Correlation between ERCC1 mRNA levels in primary colorectal cancer and those in corresponding lever metastasis. In patients with synchronous liver metastasis, ERCC1 mRNA levels in primary tumor were significantly associated with those in liver metastasis $\left(p=0.0038, r_{s}=0.84\right.$, Fig. 1A). In patients with metachronous liver metastasis, however, there was no significant correlation between ERCC1 mRNA levels in primary colorectal cancer and those in corresponding liver metastasis (Fig. 1B). There was no correlation between ERCC1 mRNA levels and clinicopathological features in Table I in this setting.

Correlation between TS mRNA levels in primary colorectal cancer and those in corresponding liver metastasis. TS mRNA levels in primary colorectal cancer were significantly associated with those in both synchronous and metachronoous liver metastasis (Fig. 2). There was no correlation between
TS mRNA levels and clinicopathological characteristics in this setting.

Gene expression in primary tumor and matched liver metastasis. In synchronous liver metastasis, there were no significant differences in mRNA levels of both ERCC1 and TS between primary colorectal cancer and corresponding liver metastasis (ERCC1, p=0.20; TS, p=0.65; Fig. 3, Table III). On the other hand, mRNA levels of ERCC1 in metachronous liver metastasis were greater than those in primary colorectal cancer ( $p=0.037$, Fig. 3A). There was the same tendency in TS mRNA expression in case of metachronous liver metastasis $(\mathrm{p}=0.0084$, Fig. 3B).

\section{Discussion}

This study demonstrated that ERCC1 mRNA levels in synchronous liver metastasis were significantly associated with those in primary colorectal cancer. In metachronous liver 
Table III. mRNA levels in primary tumor and corresponding liver metastasis.

\begin{tabular}{lccccccc}
\hline & \multicolumn{3}{c}{ Synchronous metastasis } & & \multicolumn{3}{c}{ Metachronous metastasis } \\
\cline { 2 - 3 } & Primary tumor & Liver metastasis & P-value & & Primary tumor & Liver metastasis & P-value \\
\hline ERCC1 & $0.95 \pm 0.42$ & $0.95 \pm 0.58$ & $\mathrm{p}=0.20$ & & $0.79 \pm 0.25$ & $1.09 \pm 0.67$ & $\mathrm{p}=0.037$ \\
TS & $1.74 \pm 1.12$ & $1.59 \pm 0.74$ & $\mathrm{p}=0.65$ & & $1.52 \pm 0.74$ & $2.04 \pm 0.91$ & $\mathrm{p}=0.0084$ \\
\hline
\end{tabular}

A

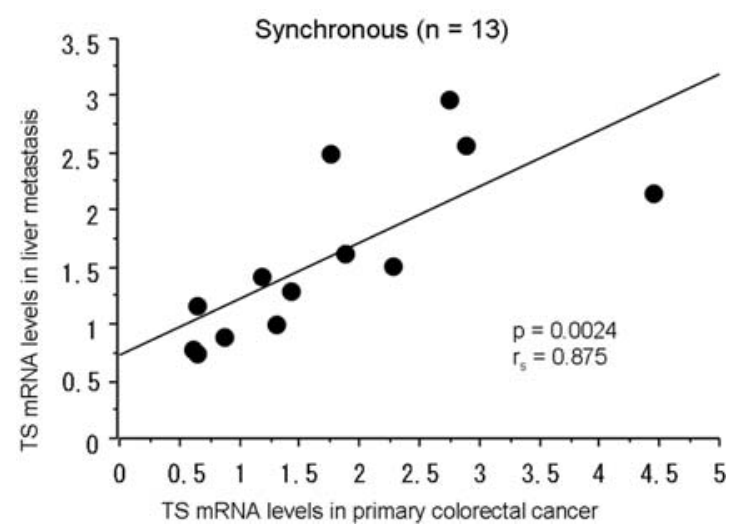

B

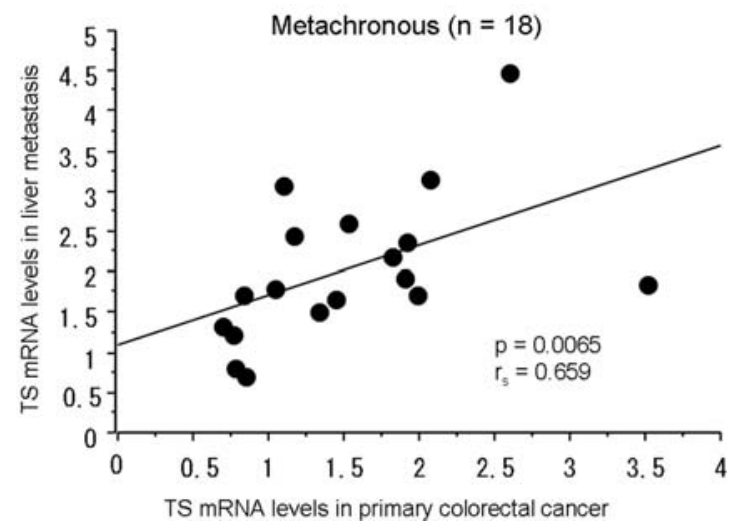

Figure 2. TS mRNA levels in primary colorectal cancer were significantly associated with those in both synchronous (A) and metachronous (B) metastasis, respectively.

A

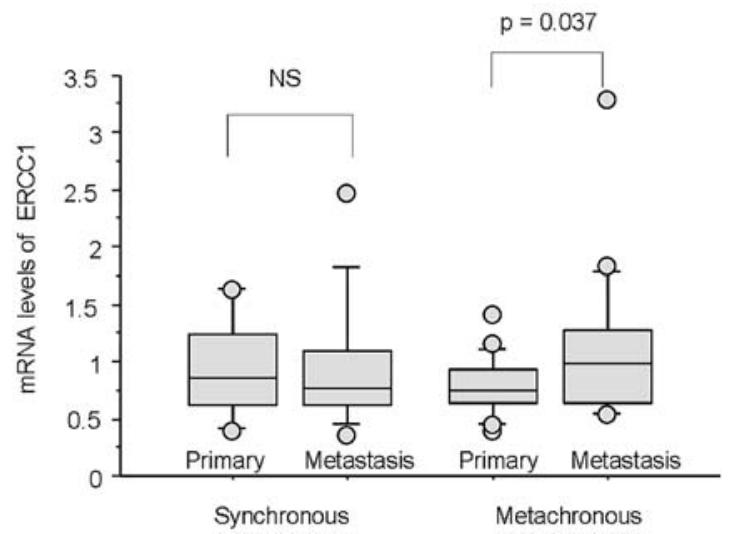

B

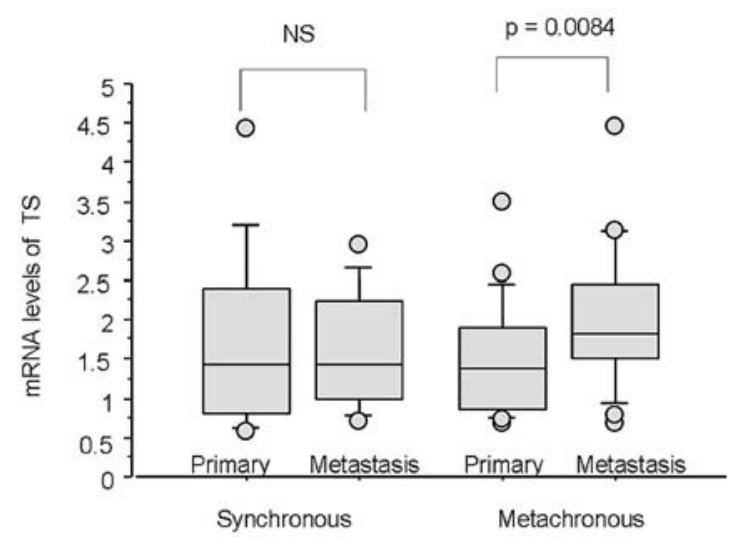

Figure 3. The expression of mRNA of ERCC1 (A) and TS (B) in primary colorectal cancer and corresponding liver metastasis. In both genes, there were no differences in mRNA levels between the primary tumor and synchronous liver metastasis. However, mRNA levels in primary tumor were significantly lower than those in metachronous liver metastasis in both ERCC1 and TS.

metastasis, however, ERCC1 mRNA levels were not correlated with those in the primary tumor. One of the reasons for this phenomenon may be the difference of circumstance for tumor growth. Median time from primary resection to hepatectomy was 2 years in this study. During this period, various factors might affect the ERCC1 mRNA levels.

Chemotherapy for advanced colorectal cancer including hematogenous metastasis, has been remarkably developed in the past several years. Oxaliplatin combined with 5-FU is one of the most promising therapies. It has been reported that FOLFOX improves survival in patients with metastatic colorectal cancer $(8,10,20,21)$. In some cases, these drugs are now used with molecular target agents such as bevacizumab (22).

Shirota et al reported that mRNA levels of TS and ERCC1 were independent predictive markers of survival for 5-FU and oxaliplatin combination chemotherapy in 5-FU-resistant metastatic colorectal cancer (17). In their study, the tumor 
samples were taken from metastatic sites of the liver or from a recurrent colorectal tumor mass. The association between ERCC1 mRNA levels in primary colorectal cancer and those in liver metastasis was not clarified.

In our study, ERCC1 mRNA and TS mRNA expression levels in patients with synchronous liver metastasis were both significantly associated with those in primary colorectal cancer. Thus, our result may indicate that in patients with synchronous liver metastasis, the gene expression levels of TS and ERCC1 in primary tumor can predict the prognosis of patients with 5-FU/oxaliplatin therapy. In patients with metachronous liver metastasis, however, ERCC1 mRNA levels in primary tumor were not associated with those in corresponding liver metastasis. Therefore, it will be required to clarify the predictors of response to FOLFOX in patients with metachronous liver metastasis.

Since 5-FU was used for the treatment of solid tumors, $>40$ years have passed. 5-FU still remains one of the most active agents used in the treatment of colorectal cancer. A number of studies have clarified that TS is a predictor of the efficacy of 5-FU-based chemotherapy as well as the prognosis in patients with those therapies, using several methods (12,23-29).

In this study, there were no differences in TS mRNA levels between primary tumor and corresponding liver metastasis. Furthermore, TS mRNA levels of primary colorectal cancer was significantly associated with those of both synchronous and metachronous liver metastasis. In metachronous liver metastasis, there was a difference in the results of gene expression between TS and ERCC1. That is, there was a positive correlation between TS mRNA levels in primary tumor and metachronous liver metastasis, but not in ERCC1. Based on these observations, the genes might respond differently to the surrounding environment, even if their expression levels were originally nearly equal.

TS expression in primary colorectal cancer and corresponding liver metastasis has been controversial. Yamada et al demonstrated that TS mRNA expression in hepatic metastases was significantly lower than in primary tumors (30). Backus et al showed that the expression of TS was significantly higher in metastases than in the matched primary tumor samples, using the method of immunohistochemical staining (31). On the other hand, Inokuchi et al reported that the TS mRNA level did not differ significantly between liver metastasis and primary tumor. In their study, no correlation was observed between primary tumor and liver metastasis (32). This discrepancy may be attributed to the stromal cells or normal tissue in their tumor specimens. To a varying degree, most of the specimens of liver metastases included stromal cells, normal liver tissue, or necrotic tissue in this study. It is considered that the technique of laser capture microdissection plays a potent role to punch out only cancer cells from specimens.

Our study also demonstrated that mRNA levels of both TS and ERCC1 in metachronous liver metastasis were higher than those in primary colorectal cancer, although those in synchronous liver metastasis were the same. This might be the result of the difference of circumstances where tumors increase in size. Cancer cells would be more modified in patients with metachronous liver metastasis than in those with synchronous one until it becomes visible as metastasis. On the other hand, in most of the stage III patients with metachronous liver metastasis, adjuvant chemotherapy was performed after curative resection for colorectal cancer. The increase of such gene expression levels might be caused by the 5-FU-based chemotherapy.

In conclusion, the measurement of mRNA levels of TS and ERCC1 in primary colorectal cancer may be useful in synchronous liver metastasis, but not in metachronous liver metastasis. These characteristics of expression of FOLFOXrelated genes in primary colorectal cancer and corresponding liver metastasis should be taken into account. However, a large clinical study will be necessary to validate this preliminary result.

\section{Acknowledgements}

This study was supported in part, by grants from the Japan Foundation for Aging and Health. We thank Yoko Takagi for her technical support.

\section{References}

1. Jemal A, Siegel R, Ward E, Murray T, Xu J, Smigal C and Thun MJ: Cancer statistics, 2006. CA Cancer J Clin 56: 106-130, 2006.

2. Muto T, Kotake K and Koyama Y: Colorectal cancer statistics in Japan: data from JSCCR registration, 1974-1993. Int J Clin Oncol 6: 171-176, 2001.

3. Weiss L, Grundmann E, Torhorst J, Hartveit F, Moberg I, Eder M, Fenoglio-Preiser CM, Napier J, Horne CH, Lopez MJ, et al: Haematogenous metastatic patterns in colonic carcinoma: an analysis of 1541 necropsies. J Pathol 150: 195-203, 1986.

4. Wolmark N, Rockette H, Mamounas E, Jones J, Wieand S, Wickerham DL, Bear HD, Atkins JN, Dimitrov NV, Glass AG, Fisher ER and Fisher B: Clinical trial to assess the relative efficacy of fluorouracil and leucovorin, fluorouracil and levamisole, and fluorouracil, leucovorin, and levamisole in patients with Dukes' B and C carcinoma of the colon: results from National Surgical Adjuvant Breast and Bowel Project C-04. J Clin Oncol 17: 3553-3559, 1999.

5. Wolmark N, Rockette H, Fisher B, Wickerham DL, Redmond C, Fisher ER, Jones J, Mamounas EP, Ore L and Petrelli NJ: The benefit of leucovorin-modulated fluorouracil as postoperative adjuvant therapy for primary colon cancer: results from National Surgical Adjuvant Breast and Bowel Project protocol C-03. J Clin Oncol 11: 1879-1887, 1993.

6. Zaniboni A: Adjuvant chemotherapy in colorectal cancer with high-dose leucovorin and fluorouracil: impact on disease-free survival and overall survival. J Clin Oncol 15: 2432-2441, 1997.

7. Woynarowski JM, Chapman WG, Napier C, Herzig MC and Juniewicz P: Sequence- and region-specificity of oxaliplatin adducts in naked and cellular DNA. Mol Pharmacol 54: 770-777, 1998.

8. de Gramont A, Figer A, Seymour M, Homerin M, Hmissi A, Cassidy J, Boni C, Cortes-Funes H, Cervantes A, Freyer G, Papamichael D, Le Bail N, Louvet C, Hendler D, de Braud F, Wilson C, Morvan F and Bonetti A: Leucovorin and fluorouracil with or without oxaliplatin as first-line treatment in advanced colorectal cancer. J Clin Oncol 18: 2938-2947, 2000.

9. Giacchetti S, Perpoint B, Zidani R, Le Bail N, Faggiuolo R, Focan C, Chollet P, Llory JF, Letourneau Y, Coudert B, Bertheaut-Cvitkovic F, Larregain-Fournier D, Le Rol A, Walter S, Adam R, Misset JL and Levi F: Phase III multicenter randomized trial of oxaliplatin added to chronomodulated fluorouracil-leucovorin as first-line treatment of metastatic colorectal cancer. J Clin Oncol 18: 136-147, 2000.

10. Goldberg RM, Sargent DJ, Morton RF, Fuchs CS, Ramanathan RK, Williamson SK, Findlay BP, Pitot $\mathrm{HC}$ and Alberts SR: A randomized controlled trial of fluorouracil plus leucovorin, irinotecan, and oxaliplatin combinations in patients with previously untreated metastatic colorectal cancer. J Clin Oncol 22: 23-30, 2004 
11. Salonga D, Danenberg KD, Johnson M, Metzger R, Groshen S, Tsao-Wei DD, Lenz HJ, Leichman CG, Leichman L, Diasio RB and Danenberg PV: Colorectal tumors responding to 5fluorouracil have low gene expression levels of dihydropyrimidine dehydrogenase, thymidylate synthase, and thymidine phosphorylase. Clin Cancer Res 6: 1322-1327, 2000.

12. Leichman CG, Lenz HJ, Leichman L, Danenberg K, Baranda J, Groshen S, Boswell W, Metzger R, Tan M and Danenberg PV: Quantitation of intratumoral thymidylate synthase expression predicts for disseminated colorectal cancer response and resistance to protracted-infusion fluorouracil and weekly leucovorin. J Clin Oncol 15: 3223-3229, 1997.

13. Reed E: Platinum-DNA adduct, nucleotide excision repair and platinum based anti-cancer chemotherapy. Cancer Treat Rev 24: 331-344, 1998.

14. Altaha R, Liang X, Yu JJ and Reed E: Excision repair cross complementing-group 1: gene expression and platinum resistance. Int J Mol Med 14: 959-970, 2004.

15. Sancar A and Reardon JT: Nucleotide excision repair in E. coli and man. Adv Protein Chem 69: 43-71, 2004.

16. Li Q, Yu JJ, Mu C, Yunmbam MK, Slavsky D, Cross CL, Bostick-Bruton F and Reed E: Association between the level of ERCC-1 expression and the repair of cisplatin-induced DNA damage in human ovarian cancer cells. Anticancer Res 20: $645-652,2000$

17. Shirota Y, Stoehlmacher J, Brabender J, Xiong YP, Uetake H, Danenberg KD, Groshen S, Tsao-Wei DD, Danenberg PV and Lenz H J: ERCC1 and thymidylate synthase mRNA levels predict survival for colorectal cancer patients receiving combination oxaliplatin and fluorouracil chemotherapy. J Clin Oncol 19: 4298-4304, 2001.

18. Lord RV, Salonga D, Danenberg KD, Peters JH, DeMeester TR, Park JM, Johansson J, Skinner KA, Chandrasoma P, DeMeester SR, Bremner CG, Tsai PI and Danenberg PV: Telomerase reverse transcriptase expression is increased early in the Barrett's metaplasia, dysplasia, adenocarcinoma sequence. J Gastrointest Surg 4: 135-142, 2000.

19. Gibson UE, Heid CA and Williams PM: A novel method for real time quantitative RT-PCR. Genome Res 6: 995-1001, 1996.

20. Andre T, Bensmaine MA, Louvet C, Francois E, Lucas V, Desseigne F, Beerblock K, Bouche O, Carola E, Merrouche Y, Morvan F, Dupont-Andre G and de Gramont A: Multicenter phase II study of bimonthly high-dose leucovorin, fluorouracil infusion, and oxaliplatin for metastatic colorectal cancer resistant to the same leucovorin and fluorouracil regimen. J Clin Oncol 17: 3560-3568, 1999.

21. Tournigand C, Andre T, Achille E, Lledo G, Flesh M, Mery-Mignard D, Quinaux E, Couteau C, Buyse M, Ganem G, Landi B, Colin P, Louvet C and de Gramont A: FOLFIRI followed by FOLFOX6 or the reverse sequence in advanced colorectal cancer: a randomized GERCOR study. J Clin Oncol 22: 229-237, 2004.

22. Hurwitz H, Fehrenbacher L, Novotny W, Cartwright T, Hainsworth J, Heim W, Berlin J, Baron A, Griffing S, Holmgren E, Ferrara N, Fyfe G, Rogers B, Ross R and Kabbinavar F: Bevacizumab plus irinotecan, fluorouracil, and leucovorin for metastatic colorectal cancer. N Engl J Med 350: 2335-2342, 2004.
23. Allegra CJ, Parr AL, Wold LE, Mahoney MR, Sargent DJ, Johnston P, Klein P, Behan K, O'Connell MJ, Levitt R, Kugler JW, Tria Tirona $M$ and Goldberg RM: Investigation of the prognostic and predictive value of thymidylate synthase, p53, and Ki-67 in patients with locally advanced colon cancer. J Clin Oncol 20: 1735-1743, 2002.

24. Aschele C, Debernardis D, Casazza S, Antonelli G, Tunesi G, Baldo C, Lionetto R, Maley F and Sobrero A: Immunohistochemical quantitation of thymidylate synthase expression in colorectal cancer metastases predicts for clinical outcome to fluorouracil-based chemotherapy. J Clin Oncol 17: 1760-1770, 1999.

25. Cascinu S, Aschele C, Barni S, Debernardis D, Baldo C, Tunesi G, Catalano V, Staccioli MP, Brenna A, Muretto P and Catalano G: Thymidylate synthase protein expression in advanced colon cancer: correlation with the site of metastasis and the clinical response to leucovorin-modulated bolus 5-fluorouracil. Clin Cancer Res 5: 1996-1999, 1999.

26. Davies MM, Johnston PG, Kaur S and Allen-Mersh TG: Colorectal liver metastasis thymidylate synthase staining correlates with response to hepatic arterial floxuridine. Clin Cancer Res 5: 325-328, 1999.

27. Edler D, Glimelius B, Hallstrom M, Jakobsen A, Johnston PG, Magnusson I, Ragnhammar P and Blomgren H: Thymidylate synthase expression in colorectal cancer: a prognostic and predictive marker of benefit from adjuvant fluorouracil-based chemotherapy. J Clin Oncol 20: 1721-1728, 2002.

28. Johnston PG, Lenz HJ, Leichman CG, Danenberg KD, Allegra CJ, Danenberg PV and Leichman L: Thymidylate synthase gene and protein expression correlate and are associated with response to 5 -fluorouracil in human colorectal and gastric tumors. Cancer Res 55: 1407-1412, 1995.

29. Paradiso A, Simone G, Petroni S, Leone B, Vallejo C, Lacava J, Romero A, Machiavelli M, De Lena M, Allegra CJ and Johnston PG: Thymidilate synthase and p53 primary tumour expression as predictive factors for advanced colorectal cancer patients. Br J Cancer 82: 560-567, 2000.

30. Yamada H, Ichikawa W, Uetake H, Shirota Y, Nihei Z, Sugihara K and Hirayama R: Thymidylate synthase gene expression in primary colorectal cancer and metastatic sites. Clin Colorectal Cancer 1: 169-174, 2001.

31. Backus HH, Van Groeningen CJ, Vos W, Dukers DF, Bloemena E, Wouters D, Pinedo HM and Peters GJ: Differential expression of cell cycle and apoptosis related proteins in colorectal mucosa, primary colon tumours, and liver metastases. J Clin Pathol 55: 206-211, 2002.

32. Inokuchi M, Uetake H, Shirota Y, Yamada H, Tajima M and Sugihara K: Gene expression of 5-fluorouracil metabolic enzymes in primary colorectal cancer and corresponding liver metastasis. Cancer Chemother Pharmacol 53: 391-396, 2004. 